Bernacchi, the physicist of the first Scott Antarctic Expedition, I902-4. The result is of obvious importance in any thecretical explanation of aurora. The plate, which is not reproduced here, deals with the diurnal variation of the frequency of aurora as seen in different geographical directions. A maximum of frequency near 3 a.m. was observed in most directions, from N. through E. to S.E., but not in all directions, e.g. west.

Fig. 2 shows in the clearest way that aurora at Cape Royds was much more in evidence to the east than to the west. The magnetic needle at Cape Royds pointed about $30^{\circ}$ east of south, i.e. the S. magnetic pole of the earth lay north of N.W. Sir Douglas seems to think that the greater frequency in the east may be due to that being the direction of the open sea, land areas prevailing to the west. It may mean, however, only that Cape Royds lies within the zone of maximum auroral frequency.

Some of the author's conclusions are very suggestive. "Making due allowance," he says (p. 206), "for the obscuring effect of daylight . . . auroral phenomena . . . at Cape Royds favour the portions of the sky which are $(a)$ directed towards, $(b)$ directed away from, the sun, having regard for the position of the

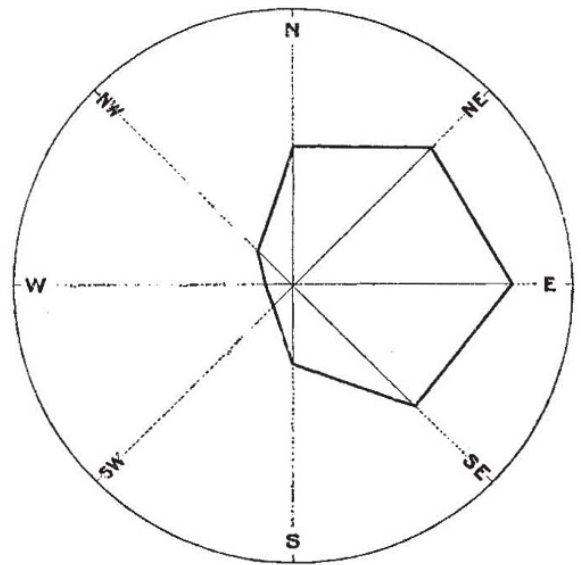

FIG. 2.-Distribution in azimuth of auroral phenomena at Cape Royds. Graphical illustration of the relative frequency of aurora seen at Cape Royds in on scale such that $x / 8$ oth in. equals one hour's display.

latter at the time of observation." Again, p. 207: "Auroral displays at Cape Royds are distinguished by the large proportion of curtains traversing the heavens in a linear, or nearly linear, direction. A remarkable daily sequence was observed in their trends. Always (on the average) they appeared directed approximately towards the sun. Thus, should a curtain persist for any length of time, it was noted always to exhibit a slow rotational movement counter-clockwise." On p. 209 we read: "After due consideration the following interpretation has been adopted: that at Cape Royds, in the case of steady, straight bands and curtains, they take up a position ... approximately directed towards the sun." In June and July aurora was visible every day when clourds permitted, but the majority of the displays in these months "were much calmer and [more] localised than during the preceding or succeeding months."

In the daily logs there are frequent indications of the observer's impression that the aurora was at no very great height, and that its form was influenced by Mt. Erebus when it lay in that direction. Thus, of an aurora on May 23 it is said :- "As it extended past the cone of Mt. Erebus, there appeared a local bend, curving outwards from the mountain ... the lower NO. 2528 , VOL. IOI] border appeared to show below the summit of the mountain." Of a curtain on May $3 \mathrm{I}$ it is said :- "It appeared to be very low over Mt. Erebus, and to touch the . . . crater. At one stage it ringed the crater." On June 2 I, we are told, "a strong luminous nebula appeared on the N. flanks of Mt. Erebus. . . . The luminous nebula stood out brightly between us and the slopes of Mt. Erebus."

In view of the apparent conflict between these observations and the measurements of auroral heights made of late years by Prof. Störmer and others in the Arctic, it is obviously desirable that the programme of the nex ${ }^{\dagger}$ Antarctic expedition should include the measurement of auroral heights after Prof. Störmer's method. A $25^{-\mathrm{km}}$. base, such as Prof. Störmer used in his latest observations, is, however, naturally fitted only for measuring great heights, so it would be well to have, in addition to a long base, a much shorter one of 2 or $3 \mathrm{~km}$., the two bases having desirably one station in common. Sir Douglas tells us that the records of the Australasian Antarctic Expedition of r912-r3 supply much fuller information as to aurora than those of the I9o8 expedition, so we may look forward to an even more valuable contribution from his pen on a future occasion.

\section{THE ANNUAL CONFERENCE OF THE NATIONAL UNION OF TEACHERS.}

THE conference of the National Union of Teachers, which was opened at Cambridge on Monday, April I, gave a welcome opportunity for a declaration of policy on the part of this large and influential body on the question of the Education Bill now before Parliament. It is satisfactory to observe that the conference resisted all amendments to the Bill on the ground that it was desirable to present to the House of Commons a clear call in favour of the general principles embodied in the Bill, and to trust to the future for any desirable amendments in its provisions. It secures at least the abolition of half-time, mainly prevailing in the textile areas of Lancashire and Yorkshire, and of the labour certificate, which took the intelligent child from the schools at a premature age. It gives the further advantage of continued education, both general and special, within the working hours of young people from fourteen to eighteen years of age, by which means two and a half millions of adolescents will continue within the healthy influence of the school in preparation for life and in the right use of leisure, and so promote a higher standard of citizenship, and thus make fruitful the early training begun in the day schools.

In the course of her presidential address Miss Conway dwelt upon the extraordinary demand which would be made on the teaching profession, not only in meeting the requirements of the new Bill, but also in supplying the grievous loss entailed by the present and future exigencies of the war. Already some 20,000 teachers out of about 37,000 have been called up for service with the Army in the field, Iooo of whom have given their lives. Women, as in so many other spheres of labour, have been called upon to fill the places of men so withdrawn, but under onerous conditions of much larger classes in schools, often disorganised, and they have nobly and successfully responded. The adequate training of the teacher is admitted to be a matter of the most serious concern, but it cannot be expected that the profession will continue to attract gifted men and women to its servire, especially that of women, upon whom the duty to a much larger extent in the future will inevitably fall, unless its status be raised, its prospects improved, its emoluments increased, and suitable retiring pensions 
provided. The advent of women in the political sphere will of necessity open up other professional careers for women, the training for which will not be more onerous than that of the teacher, and in which the prospects will be more attractive and the remuneration in proportion to the skill employed without reference to sex. Equal pay for equal service found eloquent expression at the conference, but on a division was defeated by 16,7 I 7 votes, whereupon a referendum will be taken. Despite Mr. Fisher's declaration of minimum salaries. which gave a proportion of nine-tenths to women as compared with men, the tendency to a much larger differentiation, especially in London, is on the increase, the maximum of the women headteachers in many cases in that area being actually 20 . below the minimum of the men head-teachers.

The poor remuneration of teachers is strikingly shown by a return of the Board of Education of November last, where it appeared that out of 36,827 certificated men teachers, 2639 received less than Iool. per annum, and out of 77,139 certificated women teachers, 32,314 received less than the foregoing sum. Until this matter receives drastic reform it is impossible to ensure a contented and happy body of teachers.

The provision of nursery schools, where children can have the advantage of trained nurses and medical advice, and which should be linked up with the neighbouring elementary schools, was warmly commended as tending to ensure a much better supply of healthy children. A strong plea was put forward for the employment of capable cultured women in the active work of the contemplated continuation classes, so as to give to the girls a wise training in matters relating to their responsibilities as citizens and in the duties of domestic life, and no less was it urged that men of broad sympathy and of wide academic and professional training should be placed in charge of the boys. Teachers are anxiously awaiting the enactment of the Fisher Bill, which gives effect to many of their most ardent aspirations cherished during many years. The conference adopted a scheme for the direct representation of teachers on all education committees.

\section{THE INDIGO INDUSTRY.}

$\mathrm{N}$ the Agricultural Journal for India (vol. xiii., part i., January, I9I8) Mr. W. A. Davis, indigo research chemist to the Government of India, gives a review of the present position and future prospects of the natural indigo industry. In 1896 , the year before the largescale introduction - of synthetic indigo, the combined exports of natural indigo from India and Java had a value of more than $3^{\frac{3}{4}}$ millions sterling, whilst very large additional quantities were also produced and consumed in India, China, and Japan. The value of the total world's market for indigo under pre-war conditions considerably exceeded five millions sterling, a value almost equal to that of all other artificial organic dyes put together.

The rapid displacement of the natural by the synthetic product is evidenced by the facts that whilst the exports of synthetic indigo from the German Customs district rose from 658 tons in 1895 to 16,354 tons in 1907 , the expcrts of natural indigo from India fell in the same period from 9367 tons to 1755 tons, with a further decline to 547 tons in I913-14. Nearly the whole of the last-named export consisted of the highergrade Bihar indigo, the export of the lower-grade Madras indigo having practically ceased. Again, whereas in 1897 the price of natural indigo of better quality $(60-70$ per cent.) was $7 s .-8 s$. per $1 \mathrm{~b} .$, the price in IgI4 before the war had fallen to $3 s$. per $1 \mathrm{~b}$. The number of employees engaged in indigo manufacture in India fell from 360,000 in 1880 to 30,795 in I9II.

The first effect of the war was to cause an enormous NO. 2528 , VOL. IOI] increase in the price of natural indigo, and steps were immediately taken to increase the cultivation, with the result that in $1916-17$ the total area under indigo in India was three and a half times the average of the preceding five years, although still less than one-half the area of 1895 . The statistics of the exports of synthetic indigo in the years before the war reveal the fact that China and Japan together took three-fifths of the whole production. It is very clear from these data that the prosperity of the Indian industry and its ability to compete with the synthetic product in the future will depend largely upon its being able to supply these Eastern markets. Mr. Davis is hopeful that the Indian industry will be able at least to put up a good fight, and he proposes in a future article to outline the measures of improvement which must be effected if success is to be achieved.

\section{A FRENCH SOCIETY OF CHEMICAL INDUSTRY}

THE issue of the Revue Scientifique for March 2-9 contains an interesting account of the aims and or ganisation of La Société de Chimie Industrielle, which has been established in France with the object of promoting and consolidating the development of the chemical industries of the country The formation of a society similar in character to our own Society of Chemical Industry had been under consideration before the war; the circumstances of French chemical industries during the period of the war have now given the necessary stimulus for the realisation of the project, with the full co-operation and support of the leading chemists, chemical engineers, and manufacturers of the country. The outstanding objects of the new society are to aid the development of all branches of chemical industry, to co-ordinate the labours of all workers in pure and applied chemistry for their mutual advantage, and to assist the progress of industrial chemistry not only by means of science, but also from the economic and commercial points of view. These objects, which are planned so as not to interfere with or overlap the work or publications of existing societies, are to be developed by the publication of a Review, the first number of which has already been issued, by the hold. ing of conferences, exhibitions, and competitions, and by the establishment of a bureau of industrial chemistry and of a central library. The president of the society is M. Paul Kestner; Profs. A. Haller and H. Le Chatelier are hon. presidents; MM. F. Binder, Duchemin, Matignon, and Staub vice-presidents; M. Jean Gerard general secretary; and Comte G. de Germiny treasurer.

The formation of this new society shows that in France, as in this country, the national importance of the services of chemical science needs far fuller recognition than in the past, especially in the direction of effecting that co-operation between science and industry which is fundamental for the economic development of scientific discoveries. La Société de Chimie Industrielle should do much to secure this co-operation, and we cordially wish its promoters every success in the wide and well-chosen field of their proposed activities.

\section{CIVIL SERVICE ESTIMATES FOR SCIENCE AND EDUCATION.}

THE Parliamentary Paper dealing with Class IV. of the Estimates for Civil Services for the year ending March 3I, I9I9, has now been issued. The subjoined summary gives the main items of the estimated expenditure for the year, with the details relating to scientific investigation and higher education. Reference may be made to a few particular points in these Estimates. A special grant of $30,000 l$. is included 